Borneo Journal of Sciences \& Technology, Volume (3), Issue (1), Pages: 01-06

DOI: http://doi.org/10.3570/bjost.2021.3.1-01

e-ISSN: 2672-7439

(c) 2018, UCTS Publisher.

\begin{tabular}{lll}
\hline Submitted: $10^{\text {th }}$ August 2020 & Accepted: $15^{\text {th }}$ September 2020 & Published: $31^{\text {st }}$ January 2021
\end{tabular}

\title{
Physical and Chemical Characterization of Kenaf Seed MH 8234
}

\author{
${ }^{1}$ Abdul Fattah Ab Razak, ${ }^{1}$ Mohd Zahid Abidin, ${ }^{1}$ Mohd Syafiq Abdullah, ${ }^{1}$ Ashraf A. Razak, ${ }^{1}$ Mohd Sabri \\ Mohd Afandi, ${ }^{2}$ Roselina Karim, ${ }^{2}$ Nazamid Saari, ${ }^{2}$ Wan Zunairah Wan Ibadillah, ${ }^{2}$ Sarina Abdul Halim Lim, \\ ${ }^{2,3}$ Nur Aqilah Hamim, ${ }^{2,4}$ Shafa'atu Giwa Ibrahim, and ${ }^{2}$ Nor Aini Mat Noh
}

${ }^{1}$ Food Technology Department, School of Engineering Technology, University College of Technology Sarawak (UCTS), 96000 Sibu, Sarawak, Malaysia

${ }^{2}$ Department of Food Science, Faculty of Food Science \& Technology, University Putra Malaysia (UPM), 43400 Serdang, Selangor, Malaysia

${ }^{3}$ Food Engineering Section, Malaysian Institute of Chemical \& Bioengineering Technology, University Kuala Lumpur (UniKL), 78000 Alor Gajah, Malacca, Malaysia

${ }^{4}$ Department of Biochemistry, Faculty of Science, Usmanu Danfodiyo University Sokoto, P.M.B 2346, Sokoto - Nigeria

\begin{abstract}
This study was conducted to determine the physicochemical properties of kenaf seed MH 8234. The analyses were comprised of thermogram, amino acid profile, fatty acid profile, proximate and mineral. In general, these analyses were conducted by using differential scanning calorimetry, high performance liquid chromatography, gas chromatography, atomic absorption spectroscopy. The findings show that kenaf seed MH 8234 denaturation enthalpy, onset and endset temperatures were $99.72 \mathrm{~J} / \mathrm{g}, 99.68{ }^{\circ} \mathrm{C}$ and $156.55^{\circ} \mathrm{C}$. Amino acid profile shows that kenaf seed MH 8234 is rich in L-4 -hydroxyproline (13.70\%), glutamate (3.89\%) and arginine (2.02\%). This plant material also contains an abundance amount of linoleic acid (8.88\%), oleic acid (5.97\%) and palmitic acid (4.66\%). The nutritional content of kenaf seed MH8234 comprises of crude protein (19.26\%), crude fat content (27.32\%), ash content $(5.17 \%)$, moisture content $(10.13 \%)$ and carbohydrate content $(38.12 \%)$. The conducted mineral analysis indicates that potassium $(1532 \mathrm{mg} / 100 \mathrm{~g})$, magnesium $(402 \mathrm{mg} / 100 \mathrm{~g})$ and calcium $(231 \mathrm{mg} / 100 \mathrm{~g})$ are major mineral compounds in kenaf seed MH8234. Based on the analyses shows that kenaf seed MH 8234 do have the potential as the main ingredient in products (food, pharmaceutical and nutraceutical).
\end{abstract}

Keywords: Kenaf seed MH 8234, Physicochemical Properties, Amino Acid Profile, Fatty Acid Profile, Mineral Analysis

\section{INTRODUCTION}

Kenaf (Hibiscus cannabinus L.) is part of the Malvaceae family group of Furcuria. Significantly, this plant has been related to okra, cotton, hollyhock and jute [1]. This warm-season annual plant is well known as cordage crop which functions to produce rope, sackcloth, paper, twine, building materials and animals feed [2], [3]. In Malaysia, kenaf has been spotted as a new commodity to replace tobacco plantation. This factor has been supported due to the Malaysian warm and rainy season geographical climate and the willingness of Malaysian government initiative to allocate RM 12 mil for research and development toward kenaf based industry [1], [2].

Kenaf seed (ks) has been considered as waste in agricultural practice [4]. Due to this reason, there are several initiatives taken to promote ks as main ingredient in the food product, such as ks V36 oil for dairy substitute and defatted ks V36 powder for making noodles and kenaf extract KB6 for making tofu [5]-[7]. Fundamentally, the understanding of material physical and chemical characterization is a must towards predicting and designing the potential output.

Recently, researches related to the utilisation of ks have been well studied. However, the physical and chemical characterization of ks MH8234 remain undocumented. Thus, this study was carried out to examine the physical and chemical characterization of ks 8234 which involve the analysis of: thermogram, amino acid profile, minerals, fatty acid profile and proximate.

Corresponding Author: Abdul Fattah Ab Razak, University College of Technology Sarawak (UCTS),

Email: abdul.fattah@ucts.edu.my 


\section{MATERIALS AND METHODS}

\section{Source of Ks}

Ks MH8234 were bought from Zhanpu Zhonglong Kenaf Seeds Co., Ltd, Fujian China and delivered to University College of Technology Sarawak. The sample was kept at a chilled temperature at $4^{\circ} \mathrm{C}$.

\section{Experimental Design}

Firstly, ks were undergone physical characterization which involved differential scanning calorimetry analysis. Secondly, ks were undergone chemical characterization through amino acid profile, fatty acid profile, mineral analysis and proximate analysis.

\section{Thermogram analysis}

By using differential scanning calorimetry (DSC-823E, Mettler Toledo, GmbH, Switzerland), the thermal properties of ks were calculated according to Brishti et al., 2017. The sample was weighed using analytical balance (Analytical Plus, Mettler Toledo) within the range of $(2-3 \mathrm{mg})$ and hermetically sealed in TA pans. The tested TA pans were heated at a heating rate of $10^{\circ}$ $\mathrm{C} /$ minute at 25 to $250^{\circ} \mathrm{C}$. The calibration was performed with Indium. Mettler state software system version 9.x was employed to measure four components which related to thermal properties: the onset temperature $\left(\mathrm{T}_{\mathrm{o}}\right)$, the peak temperature $\left(\mathrm{T}_{\mathrm{d}}\right)$, the enthalpy $(\Delta \mathrm{H})$ and the endset temperature $\left(\mathrm{T}_{\mathrm{e}}\right)$.

\section{Amino Acid Profile}

Analysis of amino acids was performed using High Efficiency Liquid Chromatography (Agilent 1220, Agilent Technologies) fitted with UV $338 \mathrm{~nm}$ detector, C 18, 2.5 x $200 \mathrm{~mm}$ column, $5 \mu \mathrm{m}$ column and 1:2:2 mobile phase $(100 \mathrm{mM}$ sodium sulphate, $\mathrm{pH} 7.2$; acetonitrile; $0.45 \mathrm{ml} /$ minute methanol (v/v/v) and $40{ }^{\circ} \mathrm{C}$ operating temperature.

\section{Fatty Acid Profile}

The ks oil was obtained using Soxhlet extraction unit with utilization of hexane as an extraction solvent. The extracted oil was further added with methanolic $\mathrm{NaOH}$ and blanket with $\mathrm{N}_{2}$. The solution was further heated in the oven at $100^{\circ} \mathrm{C}$ for $5 \mathrm{~min}$ and cool to room temperature. Boron trifluoride was added and blanket with $\mathrm{N}_{2}$ and well mixed. The solution was heated in the oven at $100^{\circ} \mathrm{C}$ for $5 \mathrm{~min}$, cooled and filtered through 0.45 $\mu \mathrm{m}$ Whatman $^{\circledR}$ filter paper. The filtered sample was injected to gas chromatography fitted with FID detector, $\mathrm{HP}$ - 5 column $(30 \mathrm{~m} \times 0.32 \mathrm{~mm}, 0.32 \mu \mathrm{m})$ and pressurized helium gas.

\section{Mineral Analysis}

Nine inorganic elements (sodium, calcium, magnesium, iron, potassium, manganese, zinc, copper and phosphorus) of mineral content in the sample were measured according to the method mentioned by [8] using atomic absorption spectrophotometer (240FS AA, Agilent Technologies) .

\section{Proximate analysis}

There were five components involved in this analysis, mainly: crude fat, crude protein, moisture content, ash content and carbohydrate content. All conducted methods were referred to [9]. Crude fat was conducted using Soxhlet extraction unit and petroleum ether was employed as lipid extraction solvent. The crude protein of ks is determined by applying Kjeldahl method and $6.25 \%$ factors. The moisture content and ash content of ks was measured by calculating the weight difference of sample before and after undergone oven heating at $105^{\circ} \mathrm{C}$ for 12 hours and furnace heating at $550^{\circ} \mathrm{C}$ for 12 hours. The carbohydrate content was measured by subtracting the content of nutrients from 100.

\section{RESULTS AND DISCUSSION}

Table 1: Differential scanning calorimetry (dsc) measurement for Ks MH 8234

\begin{tabular}{|c|c|}
\hline Properties & ks MH 8234 \\
\hline Enthalpy $(\Delta \mathrm{H}, \mathrm{J} / \mathrm{g})$ & $99.72 \pm 0.84$ \\
\hline Onset $\left(\mathrm{T}_{\mathrm{on}}{ }^{\circ} \mathrm{C}\right)$ & $99.68 \pm 0.32{ }^{\circ} \mathrm{C}$ \\
\hline Peak $\left(\mathrm{T}_{\mathrm{d}}{ }^{\circ} \mathrm{C}\right)$ & $123.55 \pm 0.58{ }^{\circ} \mathrm{C}$ \\
\hline Endset $\left(\mathrm{T}_{\mathrm{d}}{ }^{\circ} \mathrm{C}\right)$ & $156.55 \pm 0.66{ }^{\circ} \mathrm{C}$ \\
\hline
\end{tabular}

Table 2: Amino Acid Composition of ks MH 8234

\begin{tabular}{|c|c|}
\hline Amino Acid & Amount (\%) \\
\hline Glutamate & 3.892 \\
\hline Serine & 1.000 \\
\hline Histidine & 0.439 \\
\hline Glycine & 1.023 \\
\hline Threonine & 0.646 \\
\hline Arginine & 2.022 \\
\hline Alanine & 0.939 \\
\hline Tyrosine & 0.540 \\
\hline Valine & 0.569 \\
\hline Phenylalanine & 0.142 \\
\hline Isoleucine & 0.570 \\
\hline Leucine & 1.235 \\
\hline Lysine & 0.852 \\
\hline Asparagine & ND $(<0.001)$ \\
\hline Glutamine & ND $(<0.001)$ \\
\hline Proline & 1.276 \\
\hline Aspartate & 2.021 \\
\hline L - H - Hydroxyproline & 13.700 \\
\hline
\end{tabular}


Table 3: Free fatty acid composition of ks MH8234

\begin{tabular}{|c|c|}
\hline Free fatty acid & Amount (\%) \\
\hline Caproic Acid (C6:0) & ND $(<0.01)$ \\
\hline Caprylic Acid (C8:0) & ND $(<0.05)$ \\
\hline Capric Acid (C10:0) & ND $(<0.05)$ \\
\hline Undecanoic Acid (C11:0) & ND $(<0.05)$ \\
\hline Lauric Acid (C12:0) & 0.08 \\
\hline Tridecanoic Acid (C13:0) & ND $(<0.05)$ \\
\hline Myristic Acid (C14:0) & 0.08 \\
\hline Myristoleic Acid (14:1) & $\mathrm{ND}(<0.05)$ \\
\hline Pentadecanoic Acid (C15:0) & $\mathrm{ND}(<0.05)$ \\
\hline Cis - Pentadecanoic Acid (C15:1) & $\mathrm{ND}(<0.05)$ \\
\hline Palmitic Acid (C16:0) & 4.66 \\
\hline $\begin{array}{l}\text { Cis - Heptadecanoic Acid } \\
\text { (C17:1) }\end{array}$ & $\mathrm{ND}(<0.05)$ \\
\hline Palmitoleic Acid (C16:1) & 0.14 \\
\hline Heptadecanoic Acid (C17:0) & $\mathrm{ND}(<0.05)$ \\
\hline Stearic Acid (C18:0) & 0.74 \\
\hline Elaidic Acid (C18:1n9t) & ND $(<0.05)$ \\
\hline Oleic Acid (C18:1n9c) & 5.97 \\
\hline Linolelaidic Acid (C18:2n6t) & ND $(<0.05)$ \\
\hline Linoleic Acid (C18:2n6c) & 8.88 \\
\hline Gamma Linolenic Acid (GLA) & $\mathrm{ND}(<0.05)$ \\
\hline Arachidic Acid (C20:0) & $\mathrm{ND}(<0.05)$ \\
\hline Eicosenoic Acid (C20:1) & $\mathrm{ND}(<0.05)$ \\
\hline Alpha Linolenic Acid (C18:3n3) & 0.05 \\
\hline Heneicosanoic Acid (C21:0) & $\mathrm{ND}(<0.05)$ \\
\hline Eicosadienoic Acid & 0.11 \\
\hline $\begin{array}{c}\text { Cis - 8, 11, 14- Eicosatrienoic } \\
\text { Acid (C20:3n6) }\end{array}$ & $\mathrm{ND}(<0.05)$ \\
\hline Behenic Acid (C22:0) & $\mathrm{ND}(<0.05)$ \\
\hline Erucic Acid (C22:1n9) & $\mathrm{ND}(<0.05)$ \\
\hline Arachidonic Acid (C20:4n6) & $\mathrm{ND}(<0.05)$ \\
\hline $\begin{array}{c}\text { Cis - 11,14, } 17 \text { - Eicoastrienoic } \\
\text { Acid (C20:3n } 3)\end{array}$ & $\mathrm{ND}(<0.05)$ \\
\hline Tricosanoic Acid (C23:0) & $\mathrm{ND}(<0.05)$ \\
\hline $\begin{array}{c}\text { Eicosapentanoic Acid (EPA) } \\
(\mathrm{C} 20: 5 \mathrm{n} 3)\end{array}$ & $\mathrm{ND}(<0.05)$ \\
\hline Docosadienoic Acid (C22:2) & 0.09 \\
\hline Lignoceric Acid (C24:0) & $\mathrm{ND}(<0.05)$ \\
\hline Nervonic Acid (C24:1) & $\mathrm{ND}(<0.05)$ \\
\hline $\begin{array}{l}\text { Docohexaenoic Acid (DHA) } \\
\text { C22:6n3 }\end{array}$ & $\mathrm{ND}(<0.01)$ \\
\hline
\end{tabular}

Remarks

1. <- Less than the minimum detection limit reported; ND - Not Detected
Table 4: Mineral composition of ks MH 8234

\begin{tabular}{|c|c|}
\hline Minerals & Amount $(\mathbf{m g} / \mathbf{~ 1 0 0 g})$ \\
\hline Sodium, $\mathrm{Na}$ & 17.50 \\
\hline Calcium, $\mathrm{Ca}$ & 231.00 \\
\hline Iron, $\mathrm{Fe}$ & 4.51 \\
\hline Magnesium, $\mathrm{Mg}$ & 402.00 \\
\hline Potassium, $\mathrm{K}$ & 1532.00 \\
\hline Manganese, $\mathrm{Mn}$ & 5.78 \\
\hline Zinc, $\mathrm{Zn}$ & 6.81 \\
\hline Copper, $\mathrm{Cu}$ & 1.25 \\
\hline Phosphorus & 45.80 \\
\hline
\end{tabular}

Table 5: Proximate composition of ks MH8234

\begin{tabular}{|c|c|}
\hline Proximate & Amount (\%) \\
\hline Crude protein & $19.26 \pm 0.79$ \\
\hline Crude fat & $27.32 \pm 0.26$ \\
\hline Ash & $5.17 \pm 0.67$ \\
\hline Moisture & $10.13 \pm 0.04$ \\
\hline Carbohydrate & $38.12 \pm 0.68$ \\
\hline
\end{tabular}




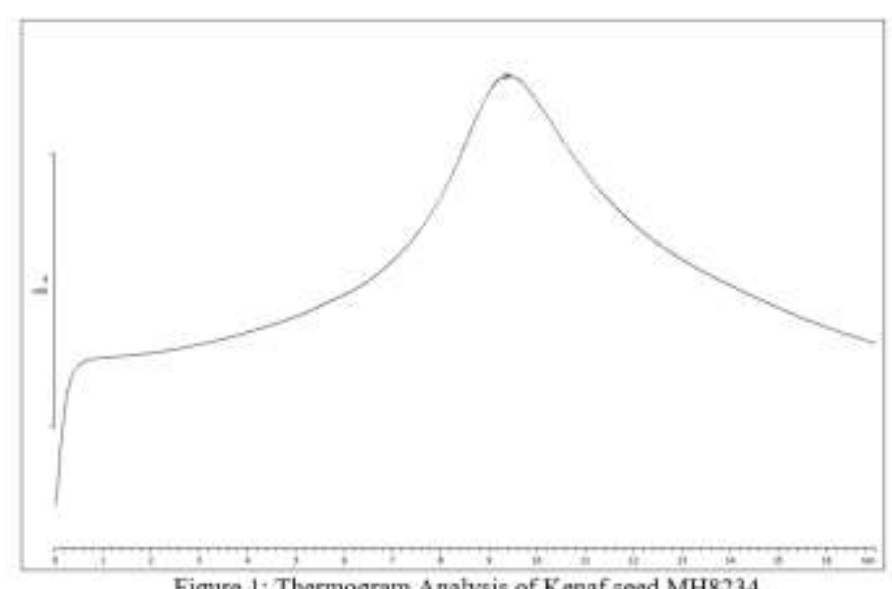

Figure 1: Thermogram Analysis of Kenaf seed MH8234

\section{Thermal Properties of ks}

Thermal analysis is conducted to determine the effect of thermal processing on plant protein. Moreover, the data gathered shall provide information about their conformational changes with the temperature of denaturation and this enable researches to predict and evaluate the sample thermal behaviour [10], [11]. The protein denaturation is visualized by the endothermic peak on the thermogram, which occurred due to unfolding of globular proteins and breakage of hydrogen bonds [12]-[16]. The thermal stability is affected by both readings - peak and endset readings. The denaturation enthalpy, onset and endset temperatures of ks MH8234 were $99.72 \mathrm{~J} / \mathrm{g}, 99.68{ }^{\circ} \mathrm{C}$ and $156.55{ }^{\circ} \mathrm{C}$. Disulphide bonds within the protein molecules and the presence of salt bridges are predicted factors towards protein thermal stability [10], [17].

\section{Amino acid profile}

The amino acid profile of ks MH 8234 shows that $\mathrm{L}-4$ - Hydroxyproline (13.70\%), glutamate (3.892\%) and arginine $(2.022 \%)$ are the predominant amino acids in $\mathrm{ks}$ MH 8234. Table 2 shows that asparagine and glutamine were not detected. According to [18] hydroxyproline is grouped under derived amino acids and this compound was mainly found in collagen. Identically, glutamate or glutamic acid is clustered under acidic amino acids and with the main function as a flavour enhancer which able to produce umami taste. Arginine is a mainly hydrophilic amino acid and mainly found in meats, dairy products and nuts [18].

\section{Fatty acid profile}

Table 3 has shwn that linoleic acid $(8.88 \%)$, oleic acid $(5.97 \%)$ and palmitic acid $(4.66 \%)$ are among the predominant fatty acid compound in ks MH8234. Generally, the displayed results percentages of ks $\mathrm{MH}$
8234 fatty acid composition is considered low as compared soybean and sesame seed [19], [20]. On the other hand, the amount of myristic acid of ks MH8234 is greater than soybean $(0.08 \%>0.06 \%)$. Processing treatment, formulation and ks variety are factors that boost the amount of ks fatty acid composition. As evidence [1], through microencapsulation, freeze-drying treatment and addition of stabilizer has generated a desirable amount of fatty acid composition which partly reason for ks oil to be fit as edible oil.

\section{Proximate analysis}

Generally, the proximate composition of food source represents the nutritional content of it. These data stood as a benchmark in directing the idea of the source towards food product development [21]. In these experiments, there were five components involved, mainly: crude protein, crude fat, ash content, moisture content and carbohydrate content. In Table 5, the crude protein content, crude fat, ash content, moisture content and carbohydrate content were found to be $19.26 \%$, $27.32 \%, 5.17 \%, 10.13 \%$ and $38.12 \%$. In comparison with data collected by [22] towards ks QP3 and V36 has revealed that the ks $\mathrm{MH} 8234$ has a greater amount of crude fat, ash content, moisture content and carbohydrate content than both varieties (QP3 \& V36). However, ks $\mathrm{MH} 8234$ has the least amount of crude protein as compared to QP3 and V36. As compared to sesame seed, ks MH 8234 has a greater amount of ash and moisture $(4.47 \%$ and $4.07 \%)$. However, it contain a lower amount of crude protein and crude fat than $(21.13 \%$ and $56.21 \%)$ [23]. As being reported by [24] towards the proximate composition of soybean seed show that this oilseed contains a greater amount of crude protein $(39.6 \%)$ and ash content $(5.7 \%)$ than ks MH8234. Nevertheless, ks $\mathrm{MH} 8234$ has a greater amount of crude fat as compared to soybean seed $(21.4 \%)$.

\section{Minerals Composition}

The minerals compositions of nutrients in the food source is linked towards the efficiency of body functioning, and the variation distribution mineral composition of plant source is affected by environmental factors and genotypic variations [25]-[28]. Fe and Zn were reported to the essential micronutrients in the human body, while magnesium is needed for muscle development and maintaining blood pressure, phosphorus and calcium are required for bone and teeth formation and sodium is required for maintaining the biological system in human body [25], [29]. The amount of minerals content reported in this study were in the middle range as compared to other types of oilseed. According to Table 4, shows that ks MH 8234 has a rich amount of potassium than a sesame seed $(851.35 \mathrm{mg} /$ $100 \mathrm{~g})$. On the other hand, sesame seed contains a greater 
amount of macrominerals and trace minerals than ks MH 8234 [20]. On the other hand, [24] reported that the soybean mineral composition: Zinc $19 \mathrm{mg} / \mathrm{kg}$ and Manganese $57 \mathrm{mg} / \mathrm{kg}$ are higher than ks MH 8234, other compounds such as potassium $21.1 \mathrm{~g} / \mathrm{kg}$, magnesium 2.7 $\mathrm{g} / \mathrm{kg}$, sodium $0.2 \mathrm{~g} / \mathrm{kg}$, calcium $5.3 \mathrm{~g} / \mathrm{kg}$ and phosphorus $7.5 \mathrm{~g} / \mathrm{kg}$ are lower than $\mathrm{ks} \mathrm{MH} 8234$.

\section{CONCLUSION}

This research was conducted to determine the physicochemical properties of ks MH 8234 which comprise of (thermal analysis, amino acid analysis, free fatty acid analysis, proximate analysis and mineral analysis). Based on the findings, it can be translated that ks MH 8234 contains essential compounds towards the human body. Thus, future studies should be focusing on developing suitable products (food, pharmaceutical and nutraceutical) which utilised ks MH 8234 as the main ingredient.

\section{ACKNOWLEDGEMENT}

Thanks are due to University College Technlogy Sarawak for financial support and University Putra Malaysia, Malaysian Institute of Chemical and Bioengineering Technology (UniKL - MICET) and Usmanu Danfodiyo University Sokoto, Nigeria for project collaboration.

\section{REFERENCES}

[1] W. L. Hue and K. L. Nyam. 2018. "Physiochemical properties of kenaf seed oil microcapsules before and after freeze drying and its storage stability," Int. Food Res. J., vol. 25, no. 4, pp. 1502-1509.

[2] A. M. M. Edeerozey, H. M. Akil, A. B. Azhar, and M. I. Z. Ariffin. 2007. "Chemical modification of kenaf fibers," Mater. Lett., vol. 61, no. 10, pp. 2023-2025.

[3] R. Coetzee, M. T. Labuschagne, and A. Hugo. 2008. "Fatty acid and oil variation in seed from kenaf (Hibiscus cannabinus L.)," Ind. Crops Prod., vol. 27, no. 1, pp. 104-109.

[4] C. L. Webber III, H. L. Bhardwaj, and V. K. Bledsoe. 2002. "Kenaf production: fiber, feed, and seed," Trends new Crop. new uses, pp. 327339.

[5] A. M. Cheong, K. W. Tan, C. P. Tan, and K. L. Nyam. 2016. "Kenaf (Hibiscus cannabinus L.) seed oil-in-water Pickering nanoemulsions stabilised by mixture of sodium caseinate, Tween 20 and $\beta$-cyclodextrin," Food Hydrocoll., vol. 52, pp. 934-941.
[6] S. G. Ibrahim, N. A. Mat Noh, W. Z. Wan Ibadullah, N. Saari, and R. Karim, "Water soaking temperature of kenaf (Hibiscus cannabinus L.) seed, coagulant types, and their concentrations affected the production of kenafbased tofu," J. Food Process. Preserv., no. April, pp. 1-13, 2020.

[7] A. M. Cheong, K. W. Tan, C. P. Tan, and K. L. Nyam, "Improvement of physical stability properties of kenaf (Hibiscus cannabinus L.) seed oil-in-water nanoemulsions," Ind. Crops Prod., vol. 80, pp. 77-85, 2016.

[8] B. Kumar, R. S. Sadagopan, R. Pandu Vasanthi, M. Kalapati, and M. Vishnuvardhan, "Comparative physico-chemical, proximate and mineral analysis on raw and roasted seeds of groundnut," Commun. Plant Sci., vol. 3, no. June, pp. 3-4, 2013.

[9] AOAC International, $A O A C$, vol. 1, no. Volume 1. 1990.

[10] F. H. Brishti, M. Zarei, S. K. S. Muhammad, M. R. Ismail-Fitry, R. Shukri, and N. Saari, "Evaluation of the functional properties of mung bean protein isolate for development of textured vegetable protein," Int. Food Res. J., vol. 24, no. 4, pp. 1595-1605, 2017.

[11] M. U. Makeri, S. A. Mohamed, R. Karim, Y. Ramakrishnan, and K. Muhammad, "Fractionation, physicochemical, and structural characterization of winged bean seed protein fractions with reference to soybean," Int. J. Food Prop., vol. 20, pp. 2220-2236, 2017.

[12] G. T. Meng and C. Y. Ma, "Thermal properties of Phaseolus angularis (red bean) globulin," Food Chem., vol. 73, no. 4, pp. 453-460, 2001.

[13] S. M. Fitzsimons, D. M. Mulvihill, and E. R. Morris, "Denaturation and aggregation processes in thermal gelation of whey proteins resolved by differential scanning calorimetry," Food Hydrocoll., vol. 21, no. 4, pp. 638-644, 2007.

[14] S. D. Arntfield and E. D. Murray, "The Influence of Processing Parameters on Food Protein Functionality I. Differential Scanning Calorimetry as an Indicator of Protein Denaturation," Can. Inst. Food Sci. Technol. J., vol. 14, no. 4, pp. 289-294, 1981.

[15] P. L. Privalov, Stability of Proteins. 1982. Stability of Proteins: Proteins which do not Present a Single Cooperative System. Advances in Protein Chemistry. Volume 35, 1982, Pages 1104. doi.org/10.1016/S0065-3233(08)60468-4

[16] X. S. Wang, C. H. Tang, X. Q. Yang, and W. R. Gao, "Characterization, amino acid composition and in vitro digestibility of hemp (Cannabis sativa L.) proteins," Food Chem., vol. 107, no. 1, pp. 11-18, 2008. 
[17] T. G. Kudre, S. Benjakul, and H. Kishimura. 2013., "Comparative study on chemical compositions and properties of protein isolates from mung bean, black bean and bambara groundnut," J. Sci. Food Agric., vol. 93, no. 10, pp. 2429-2436.

[18] S. Damodaran and K. L. Parkin, FENNEMA's FOOD CHEMISTRY, vol. FIFTH EDIT. 2017.

[19] J. L. Peñalvo, M. C. Castilho, M. I. N. Silveira, M. C. Matallana, and M. E. Torija, "Fatty acid profile of traditional soymilk," Eur. Food Res. Technol., vol. 219, no. 3, pp. 251-253, 2004.

[20] A. Asghar, M. N. Majeed, and M. N. Akhtar, "A review on the utilization of sesame as functional food," Am. J. Food. Nutr., vol. 4, no. 1, pp. 2134, 2014.

[21] F. H. Brishti, M. Zarei, S. K. S. Muhammad, M. R. Ismail-Fitry, R. Shukri, and N. Saari, "Evaluation of the functional properties of mung bean protein isolate for development of textured vegetable protein," Int. Food Res. J., vol. 24, no. 4, pp. 1595-1605, 2017.

[22] A. A. Mariod, S. F. Fathy, and M. Ismail. 2010., "Preparation and characterisation of protein concentrates from defatted kenaf seed," Food Chem., vol. 123, no. 3, pp. 747-752.

[23] M. K. Ünal and H. Yalçin, "Proximate composition of Turkish sesame seeds and characterization of their oils," Grasas y Aceites, vol. 59, no. 1, pp. 23-26, 2008.
[24] F.R.T. de Camargo, I.L. Silva, P.J.R. Barros, D.P.R. Ascheri, R.S. Rodovalho, N.C. Bellizzi, J.L.R. Ascheri, I.R. Teixeira, I.A. Devilla, A.J. de Campos. 2017. Physiological Quality of Soybean Seeds Treated with Carboxymethyl Cellulose and Fungicide. American Journal of Plant Sciences. Vol.08, No.11 (2017),10 pages 10.4236/ajps. 2017. 811185.

[25] D. K. Verma and P. P. Srivastav, "Proximate Composition, Mineral Content and Fatty Acids Analyses of Aromatic and Non-Aromatic Indian Rice," Rice Sci., vol. 24, no. 1, pp. 21-31, 2017.

[26] K. M. Wang, J. G. Wu, G. Li, D. P. Zhang, Z. W. Yang, and C. H. Shi, "Distribution of phytic acid and mineral elements in three indica rice (Oryza sativa L.) cultivars," J. Cereal Sci., vol. 54, no. 1, pp. 116-121, 2011.

[27] M. B Zimmermann and R. F. Hurrell, "Improving iron, zinc and vitamin A nutrition through plant biotechnology," Curr. Opin. Biotechnol., vol. 13, no. 2, pp. 142-145, 2002.

[28] S. L. Jiang, J. G. Wu, Y. Feng, X. E. Yang, and C. H. Shi, "Correlation analysis of mineral element contents and quality traits in milled rice (Oryza stavia L.)," J. Agric. Food Chem., vol. 55, no. 23, pp. 9608-9613, 2007.

[29] O. T. Toomer, "Nutritional chemistry of the peanut (Arachis hypogaea)," Crit. Rev. Food Sci. Nutr., vol. 58, no. 17, pp. 3042-3053, 2018. 